\section{Coming Event}

Society for the Study of Infectious Disease and the Infectious Diseases Society of America.-Joint meeting, 14-18 September, Edinburgh and Glasgow. Details from Dr R. J. Fallon, Department of Pathology, Ruchill Hospital, Glasgow N.W. (Tel. 041946 6491.)

Blackpool and Fylde Postgraduate Medical Centre.-Copies of the programme of clinical meetings for general practitioners and hospital staff, September 1970-March 1971, are obtainable from the Clinical Tutor, Victoria Hospital, Whinney Heys Road, Blackpool FY3 8NR.

Extended Course in General Medicine.Last Friday in every month, 2 p.m. from 25 September, Brook General Hospital, Shooters Hill Road, London S.E.18. Details from the postgraduate secretary at the hospital. (Tel. 01-856 5555, extn. 292.)

Sheffield Regional Psychiatric Association.-Meeting, "Forensic Psychiatry," 3 October, St. John's Hospital, London Road Lincoln. Details from Dr. J. Harding Price at the hospital.

Institute of Child Health.-Alex Simpson Smith lecture, "Forms of Congenital Deformities of the Chest and their Treatment," by Professor M. M. Ravitch (Pittsburgh University), 1 October, 5.30 p.m. Admission by ticket only. Applications to the Dean of the Institute, 30 Guilford Street, London W.C.1.

International Federation of Surgical Colleges.-Annual meeting, in association with W.H.O. and the Swiss Surgical Society, 5-7 October, Geneva. The programme includes an open symposium, "World Problems in Surgical Manpower." Details are obtainable from the Secretary, I.F.S.C. Royal College of Surgeons of England, Lincoln's Inn Fields, London WC2A 3PN.

Norfolk and Norwich Institute for Medical Education.-Details of the programme, October-November, are obtainable from the Secretary of the Institute, Norfolk and Norwich Hospital, Norwich, Norfolk NOR 53A.

Institute for the Study and Treatment of Delinquency.-_Violent Youth," a series of six monthly lectures, October-March, Wednesdays, 7.30 p.m., Caxton Hall, London S.W.1. Details and tickets (2s. 6d.) from the Institute, 8 Bourdon Street, London W.1. (Tel. 01-629 0622).

Society of Apothecaries.-The second course of instruction for the diploma in the history of medicine will begin on 10 October. Details can be obtained from Dr. F. N. L. Poynter, Honorary Secretary, Wellcome Institute of the History of Medicine, Euston Road, London N.W.1.

"Diseases of the Colon and Rectum." Course of lectures, 12-16 October, mornings, St. Mark's Hospital, City Road, London EC1V 2PS. Applications with fee ( $£ 5$ ss.) should be made to the dean of postgraduate studies.
Course in Clinical Oncology.-Series of weekly lectures and clinical discussions on tumours in all sites and systems, during the academic year 1970-1, commencing 12 October, Royal Marsden Hospital. Details and application forms from the Dean's Office, Institute of Cancer Research, 34 Sumner Place, London S.W.7.

Clinical Genetics Society.-Meeting at Royal College of Physicians of Edinburgh on 16 October. Further details from the Secretary, University Department of Human Genetics, Western General Hospital, Edinburgh.

B.M.A. (North Wales Branch).-All-day scientific meeting, 24 October, University College of North Wales. The programme includes the Welsh Oration (Sherman Foundation), "Co-existence-the Doctor and Social Worker," by Sir David Hughes Parry. A dinner ( $£ 1$ 11s.) will be held at 7.15 for 8 p.m. Applications should be made before 12 October, and details are obtainable from the B.M.A. Welsh Office, 195 Newport Road, Cardiff CF2 1UE, or from the Director of Extramural Studies, University College of North Wales, Bangor.

Chest and Heart Association.-One-day conference "Stroke Illness," 30 October, Thurso, Caithness. Fee $£ 2$ 2s. (including lunch). Details and application forms from Association, 65 North Castle Street, Edinburgh EH2 3LT.

\section{Societies and Lectures}

For attending lectures marked a fee is charged or a ticket is required. Applications
made first to the institution concerned.

\section{Monday, 14 September}

INSTITUTE OF LARYNGOLOGY AND OTOLOGY.-5.30 p.m., Combined staff consultation clinical meeting. p.m., Combined staff consultation clinical meeting.
ROYAL NORTHERN HOSPITAL POSTGRADUATE CENTRE, LONDON.-5.30 p.m., Clinicopathological conference.

Tuesday, 15 September

INSTITUTE OF OBSTETRICS AND GYNAECOLOGY.-A Hammersmith Hospital, 2 p.m., Mr. D. J. Nea Smith: Common Errors in Gynaecological Operative Technique. (Admission by ticket only,
obtainable from Secretary, Institute of Obstetrics and Gynaecology, Chelsea Hospital for Women,

SOCIETY OF MEDICAL OFFICERS OF HeAlTH : LONDON AND HOME COUNTIES BRANCH.-A London School of Hygiene and Tropical Medicine, H.30 p.m.

Friday, 18 September

NewCASTle UPON TYNe REgional NeUROLOgical CENTRE.-At Newcastle General Hospital, 5.30 p.m., Dr. H. J. M. Barnett (Ontario): Neuro30 year follow-up.

Royal Northern hospital postgraduate Centre, LONDON.-10 a.m., All-day conference on Hypertension, in honour of Professor Jacques Genest.

Sunday, 20 September

ROYAl NORTHERn HOSPITAL POSTGRADUATE CENTRE, LONDON. - 10.30 a.m., Dr. B. Seitanidis (Athens): Thalassaemia.

\section{Universities and Colleges}

QUEEN'S UNIVERSITY OF BELFAST

The following degrees were conferred at the summer graduation ceremony held on 7 July :

M.B., B.CH., B.A.O.- ${ }^{1} K$. J. Brown, ${ }^{1} R$. W. Henry, 'A. H. Jacques, 'Kathleen R. Logan, N. S. S. Adair, Dorothea E. P. Adams, J. B. Ashcroft, W. J. S. Baird, G. J. Balmer, D. Barker, R. J. Barr, J. W. Bassett, T. B. Brolly, P. A. Bromley, H. C. Brown, Phyllis E.
Buchanan, Yvonne M. Canavan, M. D. Colohan,
Deirdre Compton, Edith Cooper, J. R. Corbett, W. G Deulter, J. G. Crag, R. S. Cromey, B. J. Darby, S. I D. G. Ferguson, Delia A. Fitzpatrick, J. P. D. Flanagan, D. C. Geddis, I. H. Gibson, D. M. Goodwin, S. K. Graham, W. B. G. Gubbins, H. L. Halliday, J. N. Hamilton, J. E. Hegarty, Elizabeth C. Hobson, J. M Lemon, A. McCallion, Eileen McClelian, A. F. McClenaghan, W. W. M. McConnell, R. T. McDonald,
R. J. McFarland, P. J. McGrath, J. C. R. M. MacHenry, A. C. McKay, B. M. McKenna, C. McKibbin Katherine M. McLoughlin, Helen K. McMillen, J. K Mathilen Ran Miller D. M. M. Martin, C. D. M. F. O'Hare, D. M. Oldham, M. J. O'Reilly, Margaret C. A. Orr, R. C. Parke, Daphne W. Pollen.
M. H. Pritchard, R. J. M. Ouinn, N. A. Rainey, J. K M. H. Pritchard, R. J. M. Quinn, N. A. Rainey, J. K, B. Shanks R. Shanks, K. B. Sinanan, W. J. Stirling, R. G. N. Storey, J. E. Strong, Jean A. Trotter, Anne E. 'With second class honours.
IT

\section{Deaths}

Barbash. -On 25 August 1970, Hezekiah Barbash,
M.B., B.Ch., F.R.C.S., of 17 Ravenshall, West M.B., B.Ch., F.R.C.S., of 1775 .

Gray.-On 1 September 1970 at the South London B.Sc., M.B., Ch.B., aged 85.

\section{Correction}

Results of Vagotomy

The symptoms experienced after the operations of vagotomy and drainage and of subtotal gastrectomy were discussed in the second paragraph of the leading article (15 August, p. 358) It should have said that dumping is more frequent and severe after subtotal gastrectomy while diarrhoea is commoner after vagotomy and drainage. We regret that owing to an error these were reversed.

\section{Notice to Authors}

When original articles and letters for publication are not submitted exclusively to the British Medical fournal this must be stated.

Correspondence on editorial business should be addressed to the Editor, British Medical fournal, B.M.A. House, Tavistock Square, London WC1H 9JR. Telephone: 01-387 4499. Telegrams: Aitiology, London W.C.1.

Authors wanting reprints of their articles should notify the Publishing Manager, B.M.A. House, Tavistock Square, WC1H 9JR, on receipt of proofs.

\section{Subscriptions}

Members' subscriptions should be sent to the Secretary of the British Medical Association, B.M.A. House, London, or to the Scottish Secretary, B.M.A. Scottish Office, Drumsheugh Gardens, Edinburgh.

Doctors who are not members of the B.M.A. can subscribe to the B.M.F. The rates for doctors resident in the United Kingdom and abroad are given on the first page of the classified advertisements. These include the rate for the North American "Air Express," which is available to both members and non-members of the B.M.A.

\section{Classified Advertisements}

Doctors Abroad.-Copies of the appointment vacancies advertised in the B.M.F. can be sent by airmail on request. Members' rate: the minimum cost is 40 s. for six weeks' supply, for which copies of vacancies in up to five sections of the classified advertisements will be sent. Non-members' rate $60 \mathrm{~s}$. minimum for six weeks' supply of five headings or less. Additional headings (for members and non-members) 10s. each for six weeks' supply. Orders for specific grades in any section cannot be accepted. Payment must be prepaid and enclosed with the application.

Details of rates, etc., for classified advertisements appear on the first page of the classified section. 